\title{
The Impact of Intellectual Capital Disclosure on Firm Performance: Empirical Evidence from Pharmaceutical and Chemical Industry of Bangladesh
}

\author{
Md. Musfiqur RAHMAN* ${ }^{*}$ Raihan SOBHAN ${ }^{* *}$, Md. Shafiqul ISLAM ${ }^{* * *}$ \\ Received: November 16, 2019 Revised: December 11, 2019 Accepted: December 18, 2019
}

\begin{abstract}
The main purpose of this study is to examine the impact of intellectual capital disclosure (ICD) on firm performance in the pharmaceutical and chemical industry of Bangladesh. In this study, 21 listed pharmaceutical and chemical companies have been selected as sample for 2016 and 2017. This study used the intellectual capital disclosure index developed by Rahman, Sobhan, and Islam. Return on assets and return on equity have been used as the proxy variable of firm performance. In this study, content analysis is performed to assess the level of disclosure regarding intellectual capital and pooled cross-sectional analysis is used to assess the relationship between ICD and firm performance. The study has found a positive and significant relationship between ICD and firm performance. Besides, an in-depth analysis of this study shows that all the components of ICD namely internal capital disclosure, external capital disclosure, and human capital disclosure are also positively and significantly associated with firm performance. The study suggests the development of an intellectual capital disclosure framework by the regulatory authority for mandatory compliance. This will improve the quality and quantity of ICD in the annual reports. Besides, firms should more emphasize on ICD which will help to improve their performance.
\end{abstract}

Keywords: Intellectual Capital, Firm Performance, Internal Capital, External Capital, Human Capital.

JEL Classification Codes: M1, M14, M41, M48

\section{Introduction}

Mandatory financial reporting is becoming less informative to the investors of large highly technical firms around the world. Companies are now investing largely in R\&D projects, intangibles, and intellectual properties. But traditional financial statements do not consider the true value of these intangibles and intellectual properties. As a bridge between this existing gap of information regarding

*First Author and Corresponding Author. Associate Professor, Department of Accounting and Information Systems, University of Dhaka, Bangladesh. [Postal Address: Md. Musfiqur Rahman, Department of Accounting and Information Systems Nilkhet Road, Dhaka 1000, Bangladesh] Tel.: +88 01975529111

Email: himukobe@gmail.com

**MBA, Dept. of Accounting \& Information Systems, University of Dhaka, Bangladesh. Email: raihanfahim001@gmail.com

***Lecturer, East West University, Bangladesh.

Email: fbsshuvo@gmail.com

$\odot$ Copyright: Korean Distribution Science Association (KODISA)

This is an Open Access article distributed under the tems of the Creative Commons Attribution NonCommercial License (https:///reativecommons.orglicenses/by-nc/4.0/) which pemits unrestricted noncommercial use, distribution, and reproduction in any medium, provided the original work is properly cited. valuable intangibles and intellectual properties, a new form of corporate voluntary disclosure has emerged which is called intellectual capital disclosure. Good forms of corporate reporting help to eliminate the information asymmetries underlying the capital market investors. Madhani (2015) highlighted that new day's managers are aware of the benefits reaped from a well-presented annual report. Thus, companies that invest heavily in research, brand development and marketing of their intangibles will outperform their competitors in the barometers of corporate financial performance. However, in the Bangladeshi context, there is a dearth of research regarding the impact of intellectual capital disclosure on firm performance in the annual reports of listed companies of the pharmaceuticals and chemicals sector in Bangladesh.

The primary research question of the study is to find out the impact of intellectual capital disclosure on the firm performance of the listed companies under the pharmaceuticals and chemicals sector in Bangladesh. Intellectual capital disclosure is found to be highly affected by firm performance and other corporate governancerelated variables in Bangladesh (Rahman et al., 2019). So, it 
is also important to figure out how firm performance is affected by the extent of intellectual capital reporting in the context of Bangladesh.

So far to the best of authors' knowledge, only a handful amount of research has been conducted in the field of intellectual capital reporting in the context of Bangladesh. Previously Rahman et al. (2019), Abhayawansa and Azim (2014), Rashid (2013), Khan and Ali (2010), and Khan and Khan (2010) focused specifically on the extent of ICD in Bangladesh. There seems to have been scarcity of prior research conducted to date regarding the impact of intellectual capital disclosure in the overall firm performance in the pharmaceuticals and chemicals sector of Bangladesh. That's why this study undertook the initiative to investigate this untouched issue in the context of an emerging economy like Bangladesh.

This study adds groundbreaking contributions to the literature in several ways. Firstly, this study identifies the relationship between firm performance and intellectual disclosure exclusively in the pharmaceuticals and chemicals industry of Bangladesh and draws attention to the matter of how top-performing firms adopt better corporate reporting. Secondly, by figuring out the Intellectual Capital Disclosure (ICD) pattern in the corporate annual reports this study identifies the rate of adoption of ICD in the pharmaceuticals and chemicals industry of Bangladesh. Finally, the study will contribute to the literature on intellectual capital (IC) by filling up the gaps in the existing research.

\section{Theoretical Framework}

This section links relevant theories to the research. Most of the literature in social sciences link the relevant theories to the research to make the argumentation made in the paper stronger and more vibrant. As this paper is in the field of voluntary non-financial information disclosures, it investigates the relevant theories in this field.

\subsection{Institutional Theory and Legitimacy Theory}

Among the most widely used theories, institutional theory and legitimacy theory are the common ones (Adams, Potter, Singh, \& York, 2016; Ntim, Soobaroyen, \& Broad, 2017; Zappettini \& Unerman, 2016). Institutional theory is used to understand the frameworks used by different companies and organizations in firm-specific industry contexts (Adams et al., 2016). This theory explains how organizations use the similar type of practices and structures to make them visible as an abiding company in the eyes of the regulatory bodies and to gain substantial legitimacy which is connected to the legitimacy theory as well. Carpenter and Feroz (2001) identified the relationship of adopting a particular framework by a company with respect to its competitors that stems from pressures from the parties external to the business environment, the practice which they linked with institutional isomorphism. Another important assumption of this theory is that companies adopt new standards and frameworks in order to gain external approval in the form of reduced cost of capital and a balanced costs and benefits position (Clegg \& Hardy, 1999). Therefore, we used the insights from the institutional theory and legitimacy theory so that we can relate the performance of a firm with an extensive disclosure of intellectual capital in their corporate annual reports.

\subsection{Agency Theory}

Agency theory is used in order to identify the factors that motivate managers in today's corporations that have dispersed ownership structures. One of the important issues in agency theory is corporate governance and how it affects the disclosure of forward-looking information in the corporate annual reports. As cited by Kaur and Lodia (2014) success or failure in today's firms is largely affected by the decisions taken by the decision-makers. Therefore, we can relate that the managers in big companies have the incentive of disclosing information related to the intellectual capitals of the firm for the best interest of the principals (shareholders) of the firm. Also, in line with agency theory, information asymmetry can be appeased through better quality corporate reporting and disclosure (Ascioglu, Hegde, Krishnan, \& McDermott, 2012; Boubaker, Hamrouni, \& Liang, 2015). Rahman et al. (2019) studied intellectual capital reporting in the context of Bangladesh and linked it with agency theory. They used the internal factors such as board size, independent directors, ownership structures and other governance variables and confirms that these variables positively affect the intellectual capital disclosures in the annual reports of the firm. Thus, an effective corporate governance structure helps to solve agency problems and increase the strength of the internal control of the firm by reducing information asymmetry through voluntary corporate disclosures (Jensen \& Meckling, 1976). Hence, this study has incorporated agency theory to intellectual capital disclosure and firm performance analysis.

\section{Literature Review and Hypothesis Development}

\subsection{Intellectual Capital Disclosure (ICD) and Firm Performance}

This study has taken ROA and ROE as measures of firm 
performance and a self-structured index that captures the intellectual capital disclosure made by the firm. In this context, Khan, Muttakin, and Siddiqui (2013) studied the relationship of firm performance and corporate voluntary disclosure. They found that firms that are more profitable will disclose more voluntary information and the reason behind this is that profitable firms want to put forward a good impression towards society. A similar result was found by Hamrouni, Miloudi, and Benkraiem (2015) where they showed that willingness to disclose more voluntary information (such as intellectual capital) is vastly affected by the firm performance. But in the opposite case if a firm has a bad financial outcome then it will disclose fewer voluntary information to hide their bad performance and vice versa (Frias Aceituno, Rodriguez-Ariza, \& GarciaSanchez, 2013). Eisenhardt (1989) becomes relevant in this part of our discussion as he coined the risk of uncertainties term and linked it with forward-looking information of the companies. According to him, investors can reduce the risk of uncertainties by considering the level of risk involved within the firm by focusing on the forward-looking information disclosed (such as intellectual capital).

Beretta and Bozzolan (2008) and Zhang (2005) suggested that investors give more value to the quality of information than the quantity of information and this has a good impact on firm performance. Clarke, Seng, and Whiting (2011) used return on asset and return on equity as a measure of firm performance to capture the impact of intellectual capital disclosure in the context of Australia. They found that human capital is an important factor of Intellectual Capital (IC) that positively affects firm performance. Thus, they concluded that Australian firms are benefited highly by investing in their employees' skill and knowledge development. Anam, Fatima and Majdi (2011) found that firms with good operating profitability and growth will disclose more information regarding ICD.
Gilani and Geraily (2017) and Muttakin, Khan, and Belal (2015) found a significant relationship between ICD and firm performance in the context of Tehran and Bangladesh respectively. In contrast to them, Taliyang, Latif, and Mustafa (2012) found nonexistence of a significant relation between ICD and firm performance. As most of the studies indicate the positive relationship between ICD and firm performance, we test the following hypothesis:

Hypothesis 1: Ceteris paribus, there is a positive relationship between ICD and firm performance.

\subsection{Control Variables}

For adjusting our result regarding the impact of other factors, we have included firm size, leverage and firm age as three control variables. Regarding firm size, Bozzolan et al. (2006) studied Italy and UK firms and found that firm size as a control variable has an impact on the intellectual capital disclosure and vice versa. Whiting and Woodcock (2011) studied Australian firms and found a significant relationship between firm size and ICD. White, Lee, and Tower (2007) studied biotechnology firms in Australia and found that leverage is a significant driver for ICD controlling for both large and small size firms. Regarding firm age White et al. (2007) studied the relationship between firm age and ICD and found a positive and significant relationship. It may have happened as old firms have the legitimacy issue present in front of their investors and they try to maintain their status quo as a progressive firm by disclosing more intellectual capital-related information in their annual reports. Table-1 summarizes some important findings of previous literature in the intellectual capital disclosure and firm performance area:

Table 1: Summary of findings of some previous studies

\begin{tabular}{|c|c|c|c|c|c|c|}
\hline Study & Sample & $\begin{array}{l}\text { Time } \\
\text { Period }\end{array}$ & Method & $\begin{array}{l}\text { Dependent } \\
\text { Variables }\end{array}$ & $\begin{array}{c}\text { Independent } \\
\text { variables }\end{array}$ & Result \\
\hline $\begin{array}{l}\text { Vitolla et } \\
\text { al. (2019) }\end{array}$ & $\begin{array}{c}45 \text { reports from } \\
\text { 'Leading Practices' } \\
\text { and ' }<\text { IR }>\text { Reporters' } \\
\text { section if IIRC website }\end{array}$ & 2016-2017 & $\begin{array}{l}\text { Pooled cross- } \\
\text { sectional analysis, } \\
\text { Content } \\
\text { Analysis. } \\
\end{array}$ & ROE & ICD Quality & $\begin{array}{l}\text { ICD quality has } \\
\text { positive and significant } \\
\text { impact on ROE }\end{array}$ \\
\hline $\begin{array}{l}\text { Mukherjee } \\
\text { \& Sen } \\
(2019)\end{array}$ & $\begin{array}{l}\text { Top } 139 \text { NSE India } \\
\text { listed non-financial } \\
\text { companies }\end{array}$ & $\begin{array}{l}2011-12 \text { to } \\
2015-16\end{array}$ & $\begin{array}{l}\text { Longitudinal / } \\
\text { Panel data } \\
\text { analysis, Content } \\
\text { Analysis. }\end{array}$ & $\begin{array}{l}\text { CSG (Corporate } \\
\text { Sustainable } \\
\text { Growth) }\end{array}$ & $\begin{array}{c}\text { Value Added } \\
\text { Intellectual } \\
\text { Coefficient, Capital } \\
\text { Employed Efficiency, } \\
\text { Human Capital } \\
\text { Efficiency, Relational } \\
\text { Capital Efficiency, } \\
\text { Innovation Capital } \\
\text { Efficiency, Process } \\
\text { Capital Efficiency }\end{array}$ & $\begin{array}{l}\text { All the explanatory } \\
\text { variables such as- } \\
\text { Physical Capital, } \\
\text { Relational Capital, } \\
\text { Innovation Capital, and } \\
\text { Process Capital } \\
\text { exercise notable } \\
\text { influence in explaining } \\
\text { corporate sustainable } \\
\text { growth }\end{array}$ \\
\hline $\begin{array}{l}\text { Rahman et } \\
\text { al. (2019) }\end{array}$ & $\begin{array}{l}21 \text { Companies from } \\
\text { listed pharmaceuticals } \\
\text { and chemicals }\end{array}$ & 2016-2017 & $\begin{array}{l}\text { Pooled cross- } \\
\text { sectional analysis, } \\
\text { Content }\end{array}$ & $\begin{array}{c}\text { ICDIN } \\
\text { (Intellectual } \\
\text { capital disclosure }\end{array}$ & $\begin{array}{c}\text { Board Size, } \\
\text { Independent Director, } \\
\text { Female Directors, }\end{array}$ & $\begin{array}{l}\text { Intellectual capital } \\
\text { disclosure is positively } \\
\text { associated with firm }\end{array}$ \\
\hline
\end{tabular}




\begin{tabular}{|c|c|c|c|c|c|c|}
\hline Study & Sample & $\begin{array}{c}\text { Time } \\
\text { Period }\end{array}$ & Method & $\begin{array}{c}\text { Dependent } \\
\text { Variables }\end{array}$ & $\begin{array}{c}\text { Independent } \\
\text { variables }\end{array}$ & Result \\
\hline & $\begin{array}{l}\text { companies in Dhaka } \\
\text { Stock Exchange (DSE) }\end{array}$ & & Analysis. & index) & $\begin{array}{c}\text { Institutional } \\
\text { Ownership, Directors } \\
\text { Ownership }\end{array}$ & $\begin{array}{l}\text { size, leverage, and firm } \\
\text { performance and } \\
\text { negatively associated } \\
\text { with director ownership } \\
\text { and institutional } \\
\text { ownership }\end{array}$ \\
\hline $\begin{array}{l}\text { Isnalita \& } \\
\text { Romadhon, } \\
\text { (2018) }\end{array}$ & $\begin{array}{l}80 \text { annual reports from } \\
\text { companies listed in the } \\
\text { LQ-45 index of } \\
\text { Indonesia Stock } \\
\text { Exchange }\end{array}$ & $\begin{array}{l}2012-2013 \\
\text { (2 years) }\end{array}$ & $\begin{array}{l}\text { Purposive } \\
\text { sampling, Content } \\
\text { analysis and } \\
\text { multiple } \\
\text { regression using } \\
\text { OLS method. }\end{array}$ & $\begin{array}{l}\text { ICD (Intellectual } \\
\text { capital } \\
\text { disclosure) }\end{array}$ & $\begin{array}{l}\text { Size, Profitability, } \\
\text { Leverage, Liquidity, } \\
\text { Industrial Type, Audit } \\
\text { Committee Size, } \\
\text { Composition } \\
\text { of the Board of } \\
\text { Commissioners }\end{array}$ & $\begin{array}{c}\text { Firm size has } \\
\text { positive impact on IC } \\
\text { but profitability, } \\
\text { leverage, liquidity, } \\
\text { industry type, the audit } \\
\text { firm size, and } \\
\text { the independent } \\
\text { commissioners' } \\
\text { composition does not } \\
\text { bring significant effect. }\end{array}$ \\
\hline $\begin{array}{l}\text { Tejedo- } \\
\text { Romero \& } \\
\text { Esteves } \\
(2018)\end{array}$ & $\begin{array}{l}35 \\
\text { companies in Spanish } \\
\text { continuous market that } \\
\text { were included in the } \\
\text { IBEX 35 } \\
\text { stock index }\end{array}$ & $\begin{array}{l}2004-2008 \\
\text { (5 years) }\end{array}$ & $\begin{array}{l}\text { Content analysis } \\
\text { and multivariate } \\
\text { linear regression. }\end{array}$ & $\begin{array}{c}\text { ICD, Human } \\
\text { Capital, Structural } \\
\text { Capital, Relational } \\
\text { Capital }\end{array}$ & $\begin{array}{l}\text { Shareholder } \\
\text { concentration, } \\
\text { Independence of the } \\
\text { Board of Directors, } \\
\text { Separation of the } \\
\text { functions of the Chief } \\
\text { Executive and the } \\
\text { Chairman of the } \\
\text { Board, Size of the } \\
\text { Board of Directors }\end{array}$ & $\begin{array}{l}\text { The percentage of } \\
\text { shares held by } \\
\text { significant } \\
\text { shareholders, } \\
\text { Board Size, the } \\
\text { separation of functions } \\
\text { (CEO and } \\
\text { Chairman), and the } \\
\text { percentage of } \\
\text { independent directors } \\
\text { influence disclosure of } \\
\text { information }\end{array}$ \\
\hline $\begin{array}{l}\text { Muttakin et } \\
\text { al., (2015) }\end{array}$ & $\begin{array}{c}135 \text { non-financial } \\
\text { companies listed on } \\
\text { the } \\
\text { Dhaka Stock } \\
\text { Exchange (DSE) }\end{array}$ & $\begin{array}{l}2005-2009 \\
(5 \text { Years })\end{array}$ & $\begin{array}{l}\text { Content Analysis } \\
\text { and OLS } \\
\text { regression } \\
\text { analysis }\end{array}$ & $\begin{array}{l}\text { Intellectual capital } \\
\text { disclosure index } \\
\text { (ICDI) }\end{array}$ & $\begin{array}{l}\text { Family ownership, } \\
\text { foreign ownership, } \\
\text { board independence, } \\
\text { CEO duality, family } \\
\text { duality, audit } \\
\text { committee }\end{array}$ & $\begin{array}{c}\text { A non-linear } \\
\text { relationship between } \\
\text { family ownership and } \\
\text { ICD exists. Foreign } \\
\text { ownership, board } \\
\text { independence, and the } \\
\text { presence of audit } \\
\text { committees are } \\
\text { positively associated } \\
\text { with ICD. }\end{array}$ \\
\hline $\begin{array}{l}\text { Boujelbene } \\
\text { \& Affes } \\
\text { (2013) }\end{array}$ & $\begin{array}{l}102 \text { French companies } \\
\text { in the SBF120 French } \\
\text { index }\end{array}$ & 2009 & $\begin{array}{c}\text { Pooled cross- } \\
\text { sectional analysis, } \\
\text { Content } \\
\text { Analysis } \\
\end{array}$ & $\begin{array}{l}\text { Cost of Equity } \\
\text { Capital }\end{array}$ & ICD in annual reports & $\begin{array}{l}\text { ICD is negatively and } \\
\text { significantly related to } \\
\text { cost of equity }\end{array}$ \\
\hline $\begin{array}{l}\text { Clarke et } \\
\text { al., (2011) }\end{array}$ & $\begin{array}{c}3944 \text { firms listed in } \\
\text { Australian Stock } \\
\text { Exchange }\end{array}$ & $\begin{array}{l}2004-2008 \\
(5 \text { years })\end{array}$ & $\begin{array}{l}\text { OLS regression } \\
\text { analysis }\end{array}$ & $\begin{array}{c}\text { Return on Assets, } \\
\text { Return on Equity, } \\
\text { Revenue Growth, } \\
\text { Employee } \\
\text { Productivity }\end{array}$ & $\begin{array}{c}\text { Value Added } \\
\text { Intellectual } \\
\text { Coefficient, Capital } \\
\text { Employed Efficiency, } \\
\text { Human Capital } \\
\text { Efficiency, Structural } \\
\text { Capital Efficiency, } \\
\text { Leverage, Research } \\
\text { Intensity, Year, } \\
\text { Industry }\end{array}$ & $\begin{array}{c}\text { Capital employed } \\
\text { efficiency and human } \\
\text { capital efficiency have } \\
\text { direct impact on firm } \\
\text { performance. A } \\
\text { positive relationship } \\
\text { between IC (human } \\
\text { and structural capital) } \\
\text { in the prior year } \\
\text { and performance in the } \\
\text { current year is evident. }\end{array}$ \\
\hline $\begin{array}{l}\text { Orens et al. } \\
\text { (2009) }\end{array}$ & $\begin{array}{l}267 \text { non-financial } \\
\text { listed firms from } \\
\text { continental Europe }\end{array}$ & 2002 & $\begin{array}{l}\text { Content analysis, } \\
\text { Simultaneous } \\
\text { regression } \\
\text { Modelling }\end{array}$ & $\begin{array}{l}\text { Tobin's Q, } \\
\text { Information } \\
\text { Asymmetry. } \\
\text { Cost of Capital }\end{array}$ & $\begin{array}{l}\text { Web-based IC } \\
\text { reporting }\end{array}$ & $\begin{array}{l}\text { The extent of ICD } \\
\text { disclosure is positively } \\
\text { associated with firm } \\
\text { value and has a } \\
\text { negative impact on } \\
\text { information asymmetry } \\
\text { and cost of capital }\end{array}$ \\
\hline $\begin{array}{l}\text { Abdolmoha } \\
\text { mmadi } \\
(2005)\end{array}$ & $\begin{array}{l}58 \text { Fortune } 500 \\
\text { companies }\end{array}$ & 1993-1997 & $\begin{array}{l}\text { Pooled cross- } \\
\text { sectional analysis, } \\
\text { Content } \\
\text { Analysis } \\
\end{array}$ & $\begin{array}{c}\text { Market } \\
\text { Capitalization }\end{array}$ & ICD in annual reports & $\begin{array}{c}\text { ICD is positively } \\
\text { associated with market } \\
\text { capitalization }\end{array}$ \\
\hline
\end{tabular}




\section{Research Design}

\subsection{Sample and Data}

In order to conduct the research, samples were taken from the companies of pharmaceuticals and chemicals industry listed in Dhaka Stock Exchange (DSE) of Bangladesh. The study was conducted for the years 2016 and 2017. There are, at present, 32 listed pharmaceutical and chemical companies in Bangladesh of which, 4 were listed in 2018. Out of the rest 28 companies, 21 companies had similar accounting period from July to June. As a result, the final sample size was 21 listed companies for 2 years, resulting in a sample size of 42 firm-years. All of the data were taken from secondary source i.e. the annual reports of the companies. The list of the companies included in the sample is given in Table-2 below:

Table 2: List of sample companies

\begin{tabular}{|c|c|c|c|}
\hline Serial & Name of the Company & Serial & Name of the Company \\
\hline 1 & ACI Limited & 12 & The IBN SINA Pharmaceutical Industry Ltd. \\
\hline 2 & ACI Formulations Limited & 13 & Keya Cosmetics Ltd. \\
\hline 3 & The ACME Laboratories Limited & 14 & Kohinoor Chemicals Company (Bangladesh) Ltd. \\
\hline 4 & Active Fine Chemicals Limited & 15 & The IBN SINA Pharmaceutical Industry Ltd. \\
\hline 5 & AFC Agro Biotech Ltd. & 16 & Keya Cosmetics Ltd. \\
\hline 6 & Beacon Pharmaceuticals Limited & 17 & Kohinoor Chemicals Company (Bangladesh) Ltd. \\
\hline 7 & Beximco Pharmaceuticals Ltd. & 18 & The IBN SINA Pharmaceutical Industry Ltd. \\
\hline 8 & Beximco Synthetics Ltd. & 19 & Keya Cosmetics Ltd. \\
\hline 9 & Central Pharmaceuticals Limited & 20 & Kohinoor Chemicals Company (Bangladesh) Ltd. \\
\hline 10 & Far Chemical Industries Limited & \multirow{2}{*}{21} & The IBN SINA Pharmaceutical Industry Ltd. \\
\hline 11 & Global Heavy Chemicals Limited & & \\
\hline
\end{tabular}

\subsection{Research Model}

In this study, the pooled cross-sectional method has been used for testing the hypothesis. For measuring the dependent variable (firm performance), two performance measures (ROA and ROE) are used.

In order to determine the independent variable, ICD, a checklist was used. The checklist was taken from Rahman et al. (2019) that consists of 24 items. The items included in the checklist of ICD was divided into three groups: disclosures regarding internal capital (8 items), disclosures regarding external capital ( 8 items) and disclosures regarding human capital ( 8 items). After that content analysis was conducted using the un-weighted method. If the item mentioned in the checklist was present in a firm's annual report, it was scored 1 . If not, it was scored 0 . After performing the content analysis, an index was developed. The index was calculated by dividing the total score achieved by a company by total achievable score (Li,
Huang, Du, \& Lin, 2007; Muttakin et al., 2015). For calculating the ICD index (ICDIN), the following formula was used:

$$
\operatorname{ICDIN}_{j}=\frac{\sum_{t=1}^{n} X_{i j}}{n_{j}}
$$

Where $n_{j}=$ number of items for jth firm, $X_{i j}=1$ if $i^{\text {th }}$ item disclosed, 0 if $i^{\text {th }}$ item not disclosed, so that $0 \leq \operatorname{ICDIN}_{j} \leq 1$.

In order to explore the impact of ICD on firm performance, a multivariate analysis was done. For this, the following regression equations were used:

$$
\begin{aligned}
\text { ROA }= & \alpha+\beta_{1} \text { ICDIN }+\beta_{2} \text { LNFSZ }+\beta_{3} \text { LEV } \\
& +\beta_{4} \text { LNFAGE }+\varepsilon \\
\text { ROE }= & \alpha+\beta_{1} \text { ICDIN }+\beta_{2} \text { LNFSZ }+\beta_{3} \text { LEV } \\
& +\beta_{4} \text { LNFAGE }+\varepsilon
\end{aligned}
$$

The explanation of variables used in the equations is given in the Table-3 below:

Table 3: Definition of Variables

\begin{tabular}{|l|l|l|c|}
\hline Variable Name & Symbol & Explanation & Expected Relation \\
\hline Dependent Variable & ROA & Ratio of Net Profit Before Tax to Average Total Assets & \\
\hline Return on Asset & ROE & Ratio of Net Profit Before Tax to Average Total Equity & \\
\hline Return on Equity & Index value of intellectual capital disclosure & \\
\hline Independent Variable & ICDIN & Natural Logarithm of Book Value of Total Assets & + \\
\hline Intellectual Capital Disclosure Index & \multicolumn{5}{|l|}{} \\
\hline Control Variables & LNFSZ & Ratio of Book value of Total Debt to Total Assets & + \\
\hline Firm Size & LEV & Natural Logarithm of firm's age since inception. & $+/-$ \\
\hline Leverage & LNFAGE & + \\
\hline Firm Age &
\end{tabular}




\section{Results}

\subsection{Descriptive Statistics}

The descriptive statistics of the index for ICD and its components are presented in Table 4. From this table it can be seen that the overall mean value of ICD index is 0.498 which indicates that companies in the pharmaceuticals and chemicals industry of Bangladesh have disclosed $49.8 \%$ of the items included in the checklist. The minimum disclosure was $13 \%$ whereas one of the sample companies have the highest disclosure rate of $83 \%$.

Table 4: Descriptive Statistics of Intellectual Capital Disclosure Index (2017 and 2016)

\begin{tabular}{|c|c|c|c|c|c|c|c|c|c|}
\hline \multirow{2}{*}{ Variable Name } & \multirow{2}{*}{ Symbol } & \multirow{2}{*}{$\mathbf{N}$} & \multirow{2}{*}{ Mean } & \multirow{2}{*}{ SD } & \multirow{2}{*}{ Min } & \multirow{2}{*}{ Max } & \multirow{2}{*}{ Med } & \multicolumn{2}{|c|}{ Mean } \\
\hline & & & & & & & & 2016 & 2017 \\
\hline Internal Capital Disclosure Index & intcin & 42 & 0.595 & 0.187 & 0.250 & 1 & 0.5 & 0.591 & 0.598 \\
\hline External Capital Disclosure Index & excin & 42 & 0.487 & 0.255 & 0 & 0.800 & 0.5 & 0.491 & 0.483 \\
\hline Human Capital Disclosure Index & hcin & 42 & 0.467 & 0.225 & 0.130 & 0.880 & 0.5 & 0.455 & 0.479 \\
\hline Intellectual Capital Disclosure Index & icdin & 42 & 0.498 & 0.202 & 0.130 & 0.830 & 0.5 & 0.494 & 0.502 \\
\hline
\end{tabular}

The results are not satisfactory enough considering the importance of ICD for a company. Among the three subcategories, the index value of internal capital disclosure has the highest mean, followed by external capital disclosure. The human capital disclosure index has the lowest mean value indicating the indifference of the companies in disclosing these issues. Among these three, the maximum value is 1 which can be found in the internal capital disclosure index whereas the external capital disclosure index has the minimum value of 0 . The mean values of both internal and human capital disclosure indices have increased from 2016 to 2017 but the mean value has slightly decreased for the external capital disclosure index. Although the overall mean value of ICD index is not quite satisfactory (almost 50\%), the scenario is improving gradually. Abhayawansa and Azim (2014) conducted a study in the same industry and found that the mean value of ICD is $43.24 \%$ (14.7 out of 34 items on an average).
Besides, the mean value of ICD index has increased from $49.4 \%$ in 2016 to $50.2 \%$ in 2017 . From this, it can be expected that the disclosure practice of intellectual capital will increase gradually in the future ahead.

The descriptive statistics for the dependent variables and control variables are provided in Table 5. From the table, it can be seen that the mean ROA of the sample companies is $12.83 \%$. The minimum value of ROA is $-6.84 \%$, indicating a loss before tax whereas the maximum value is $56.09 \%$. The mean value of ROE is $22.39 \%$. The minimum value of $\mathrm{ROE}$ is $-11.85 \%$ and the maximum value is $117.2 \%$.

Among the control variables, the firm size has a mean value of BDT 11351 million with a minimum value of BDT 207.7 million and a maximum value of BDT 45763 million. The mean value of leverage is $36.87 \%$ with a minimum value of $1.93 \%$ and a maximum value of $75.56 \%$. Finally, the mean firm, size is 29.024 years with a minimum value of 4 years and a maximum value of 63 years.

Table 5: Descriptive Statistics of other variables

\begin{tabular}{|l|l|l|l|l|l|l|l|}
\hline Variable Name & Symbol & N & Mean & SD & Min & Max & Med \\
\hline ROA (\%) & roa & 42 & 12.83 & 12.34 & -6.840 & 56.09 & 8.3667 \\
\hline ROE (\%) & roe & 42 & 22.39 & 24.8 & -11.85 & 117.2 & 14.9 \\
\hline Firm Size (in million) & fsz & 42 & 11,351 & 13,180 & 207.7 & 45,763 & 4427.31 \\
\hline Leverage (\%) & lev & 42 & 36.87 & 18.75 & 1.93 & 75.56 & 36.803 \\
\hline Firm Age & fage & 42 & 29.024 & 17.631 & 4 & 63 & 21.5 \\
\hline
\end{tabular}

\subsection{Bivariate Analysis}

Table-6 represents Pearson's correlation matrix. From the table, it can be seen that ROA is positively correlated to ICDIN at 5\% significance level. However, it has a negative correlation with firm size $(\ln )$, leverage and firm age $(\ln )$. Only the correlation between ROA and leverage is significant at $1 \%$. There is also a positive correlation between ROE and ICDIN at 5\% significance level. It implies that increased disclosure regarding intellectual capital can improve firm performance (both ROA and ROE). ROE is also positively correlated to firm age (ln) and negatively correlated to firm size $(\ln )$ and leverage but the correlation is not significant enough. 
Table 6: Correlation Matrix

\begin{tabular}{|l|l|l|l|l|l|l|}
\hline \multicolumn{1}{|c|}{ Variables } & \multicolumn{1}{|c|}{ ROA } & \multicolumn{1}{|c|}{ ROE } & \multicolumn{1}{|c|}{ ICDIN } & \multicolumn{1}{|c|}{ Firm Size } & Leverage & \multicolumn{1}{c|}{ Firm Age } \\
\hline ROA & 1 & & & & & \\
\hline ROE & $0.921^{* * *}$ & 1 & & & & \\
\hline ICDIN & $0.346^{*}$ & $0.347^{*}$ & 1 & & & \\
\hline Firm Size (ln) & -0.058 & -0.141 & $0.400^{* *}$ & 1 & & \\
\hline Leverage & $-0.443^{* *}$ & -0.219 & -0.057 & 0.053 & 1 & \\
\hline Firm Age $(\ln )$ & -0.022 & 0.0434 & $0.428^{* *}$ & $0.372^{*}$ & 0.131 & 1 \\
\hline
\end{tabular}

${ }^{*} p<0.05,{ }^{* *} p<0.01,{ }^{* * *} p<0.001$

Table-7 represents the variance inflation factor (VIF) of the regression models. The VIF test is done to assess whether there is any presence of multicollinearity problem in the models. The lowest VIF is 1.04 for leverage and the highest VIF is 1.36 for ICD index. According to Greene
(2008), there is no presence of multicollinearity problem if the mean VIF is less than 10. In this model, the mean VIF is 1.25. So the multicollinearity problem is absent in this model.

Table 7: Variance Inflation Factor (VIF)

\begin{tabular}{|c|c|c|}
\hline Variable & VIF & 1/VIF \\
\hline ICD Index & 1.36 & 0.73664 \\
\hline Firm Size (Ln) & 1.27 & 0.78928 \\
\hline Leverage & 1.04 & 0.96534 \\
\hline Firm Age (Ln) & 1.33 & 0.74992 \\
\hline Mean VIF & $\mathbf{1 . 2 5}$ & \\
\hline
\end{tabular}

\subsection{Multivariate Analysis}

Table- 8 represents the results of the regression models. Both OLS model and lag model were used to assess the relationship between firm performance and ICD. From the table, it can be seen that ICD index is positively and significantly related to firm performance (both ROA and ROE) in both OLS model and lag model. It means firms that disclose more information regarding intellectual capital tend to perform well compared to others. Voluntary disclosures like ICD can make a positive impression to different stakeholders that can positively influence firm performance. Besides, forward-looking information like ICD can reduce information asymmetry that can positively impact firm performance (Vitolla, Raimo, \& Rubino, 2019). This result is consistent with the institutional theory and legitimacy theory because extensive disclosure of voluntary information helps a firm to gain external approval in the form of reduced cost of capital that can improve the performance of the firm. Thus Hypothesis-1 can be accepted.

Among the control variables, firm size and firm age are insignificantly related to firm performance. However, there is a negative and significant relationship between leverage and ROA in both OLS model and lag model. It is consistent with the study conducted by Lin and Change (2011) where it was found that excessive debt can increase the finance cost of a firm that can deteriorate firm performance.

Table 8: Regression Results of Impact of ICDI on Firm Performance

\begin{tabular}{|c|c|c|c|c|c|c|}
\hline \multirow{2}{*}{ Variable Name } & \multirow{2}{*}{ Symbol } & \multirow{2}{*}{ Expectation } & \multicolumn{2}{|c|}{ Model 1 (ROA) } & \multicolumn{2}{|c|}{ Model 2 (ROE) } \\
\hline & & & OLS & Lag & OLS & Lag \\
\hline \multirow[t]{2}{*}{ ICD Index } & ICDIN & + & $0.2629^{* * *}$ & $0.3018^{*}$ & $0.5756^{* *}$ & $0.6833^{* *}$ \\
\hline & & & $(0.009)$ & $(0.054)$ & $(0.037)$ & $(0.045)$ \\
\hline \multirow[t]{2}{*}{ Firm Size } & LNFSZ & + & -0.0149 & -0.0180 & -0.0534 & -0.0515 \\
\hline & & & $(0.252)$ & $(0.364)$ & $(0.211)$ & $(0.233)$ \\
\hline \multirow[t]{2}{*}{ Leverage } & LEV & $+/-$ & $-0.3349^{* * *}$ & $-0.3216^{* *}$ & -0.2937 & -0.3335 \\
\hline & & & $(0.006)$ & $(0.077)$ & $(0.227)$ & $(0.378)$ \\
\hline \multirow[t]{2}{*}{ Firm Age } & LNFAGE & + & -0.0006 & -0.0006 & -0.0003 & -0.0007 \\
\hline & & & $(0.570)$ & $(0.726)$ & $(0.903)$ & $(0.842)$ \\
\hline R-squared & & & 0.5566 & 0.5761 & 0.4437 & 0.4982 \\
\hline
\end{tabular}

${ }^{*} p<0.10,{ }^{* *} p<0.05,{ }^{* * *} p<0.01$ 
Table-9 represents the regression results of the impact of internal capital disclosure index (INTCIN) on firm performance. In can be seen that INTCIN has a positive and significant impact on firm performance at $1 \%$ significance level. It implies that disclosing matters regarding firm's intellectual properties, corporate culture, financial relations, management processes etc. can provide in-depth knowledge about the firm's internal capital to the stakeholders and can reduce information asymmetry. This will ultimately lead to the reduction of cost of capital and improvement of firm performance. Among the control variables, only leverage is negatively and significantly related to ROA in this model.

Table 9: Regression Results of Impact of INTCIN on Firm Performance

\begin{tabular}{|l|c|c|c|c|}
\hline Variable Name & Symbol & Expectation & Model 1 (ROA) & Model 2 (ROE) \\
\hline Internal Capital Disclosure Index & INTCIN & + & $0.3137^{* * *}$ & $0.6907^{* * *}$ \\
\hline & & & $(0.001)$ & $(0.001)$ \\
\hline Firm Size & LNFSZ & + & -0.0076 & -0.0373 \\
\hline & & & $(0.521)$ & $(0.144)$ \\
\hline Leverage & LEV & - & $-0.3346^{* * *}$ & -0.2924 \\
\hline Firm Age & & & $(0.004)$ & $(0.217)$ \\
\hline & LNFAGE & + & -0.0006 & -0.0002 \\
\hline
\end{tabular}

${ }^{*} p<0.10,{ }^{* *} p<0.05,{ }^{* * *} p<0.01$

Table-10 represents the regression results of the impact of external capital disclosure index (EXCIN) on firm performance. The results found a positive and significant relationship between EXCIN and firm performance. However, the significance level is $10 \%$ for ROA and $5 \%$ for
ROE. It implies that disclosures regarding brand, customer satisfaction, favorable contracts, quality standards etc. not only create a favorable image in front of the stakeholders but also act as a medium of advertisement that ultimately improves firm performance.

Table 10: Regression Results of Impact of EXCIN on Firm Performance

\begin{tabular}{|c|c|c|c|c|}
\hline Variable Name & Symbol & Expectation & Model 1 (ROA) & Model 2 (ROE) \\
\hline External Capital Disclosure Index & EXCIN & + & $0.1252^{*}$ & $0.3149^{* *}$ \\
\hline Firm Size & & & $(0.087)$ & $(0.044)$ \\
\hline Leverage & LNFSZ & + & -0.0084 & -0.0402 \\
\hline Firm Age & & & $(0.528)$ & $(0.157)$ \\
\hline & LEV & - & $-0.3723^{* * *}$ & $(0.151)$ \\
\hline & & & $(0.004)$ & 0.0012 \\
\hline
\end{tabular}

${ }^{*} p<0.10,{ }^{* *} p<0.05,{ }^{* * *} p<0.01$

Table 11: Regression Results of Impact of HCIN on Firm Performance

\begin{tabular}{|c|c|c|c|c|}
\hline Variable Name & Symbol & Expectation & Model 1 (ROA) & Model 2 (ROE) \\
\hline Human Capital Disclosure Index & HCIN & + & $0.2028^{* *}$ & $0.3737^{*}$ \\
\hline & & & $-0.037)$ & $(0.077)$ \\
\hline Firm Size & LNFSZ & + & $(0.311)$ & -0.0477 \\
\hline Leverage & & $-0.3212^{* *}$ & $(0.112)$ \\
\hline Firm Age & LEV & -0.2831 & $(0.012)$ & $(0.291)$ \\
\hline & & + & -0.0007 & $(0.576)$ \\
\hline
\end{tabular}

Table-11 represents the regression results of human capital disclosure index (HCIN) on firm performance. It can be seen that there is a positive and significant relationship between HCIN and firm performance. However, the significance level is $5 \%$ for ROA and $10 \%$ for ROE. The regression results imply that disclosures regarding 
employee know-how, training program, union activity, employee safety, and health can help to communicate to different stakeholders and organizational performance can be enriched by this communication (Lin, Huang, Du, \& Lin, 2012).

\section{Conclusion and Recommendation}

This paper aimed to examine the relationship between ICD disclosure and firm performance in the pharmaceutical and chemical industry of Bangladesh. As indicators of firm performance, two variables were taken namely ROA and ROE. As there is no existence of any mandatory guidelines regarding ICD, it remains a voluntary disclosure in Bangladesh. As a result, the extent of disclosure is still quite low. On the basis of the checklist developed by Rahman et al. (2019), only $49.8 \%$ of the items were disclosed during 2016 and 2017. ROA and ROE have mean values of $12.83 \%$ and $22.39 \%$ which indicates good profitability of the industry.

This paper found a positive and significant relationship between firm performance and ICD. The companies with higher disclosure status tend to perform well in the pharmaceutical and chemical industry. This finding is consistent with the studies conducted by Vitolla et al. (2019) and Lin et al. (2012). Disclosures regarding intellectual capital can lessen information asymmetry which will reduce cost of capital and finance cost, ultimately leading to better performance (Orens, Aerts, \& Lybaert, 2009; Boujelbene \& Affes, 2013). Higher ICD can also increase market capitalization that will aid in improving firm performance (Abdolmohammadi, 2005; Taliyang, Harun, Mustafa, \& Mansor, 2014). This study also found that all the components of ICD namely internal capital disclosure, external capital disclosure and human capital disclosure all are positively and significantly related to firm performance. By disclosing extensively regarding intellectual capital, firms can achieve a lower cost of capital and higher performance in the market.

The study has several implications. This study shows a lower amount of disclosures regarding intellectual capital which is a matter of concern. Respective authorities and policymakers should develop a mandatory framework regarding intellectual capital like Corporate Governance Code, 2018. In fact, a separate section can be kept for ICD in the annual reports. This will not only improve the extent of ICD but also will aid market participants in collecting future-oriented information at a lower cost. The companies should be educated on the fact that higher disclosures regarding intellectual capital will help to reduce the cost of capital and increase profitability.

However, there are some limitations of this study. The sample has been taken for only two years. Besides, the study is limited to pharmaceutical and chemical industry only. So there is a need for further research to support the findings. This study can be extended to different industries for more years. Besides, an improved index can be developed by including more items in the checklist. Finally, other performance indicators like Tobin's Q, growth, share returns can be used to assess the relationship between ICD and performance.

\section{Reference}

Abdolmohammadi, M. J. (2005). Intellectual capital disclosure and market capitalization. Journal of Intellectual Capital, 6(3), 397- 416.

Anam, O. A.., Fatima A. H., \& Majdi, A. R. H. (2011). Effects of intellectual capital information disclosed in annual reports on market capitalization: evidence from Bursa Malaysia. Journal of Human Resource Costing \& Accounting, 15(2), 85-101.

Abhayawansa, S., \& Azim, M. (2014). Corporate Reporting of Intellectual Capital: Evidence from the Bangladeshi Pharmaceutical Sector. Asian Review of Accounting, 22(2), $98-127$.

Adams, C. A., Potter, B., Singh, P. J., \& York, J. (2016). Exploring the implications of integrated reporting for social investment (disclosures). The British Accounting Review, 48(3), 283-296.

Ascioglu, A., Hegde, S. P., Krishnan, G. V., \& McDermott, J. B. (2012). Earnings management and market liquidity. Review of Quantitative Finance and Accounting, 38(2), 257-274.

Beretta, S., \& Bozzolan, S. (2008). Quality versus quantity: the case of forward-looking disclosure. Journal of Accounting, Auditing \& Finance, 23(3), 333-376.

Boubaker, S., Hamrouni, A., \& Liang, Q. B. (2015). Corporate governance, voluntary disclosure, and firm information environment. Journal of Applied Business Research, 31(1), 89-102.

Boujelbene, M. A., \& Affes, H. (2013). The impact of intellectual capital disclosure on cost of equity capital: A case of French firms. Journal of Economics, Finance and Administrative Science, 18(34), 45-53.

Bozzolan, S., O'Regan, P., \& Ricceri, F. (2006). Intellectual capital disclosure (ICD) A comparison of Italy and the UK. Journal of Human Resource Costing \& Accounting, 10(2), 92-113.

Carpenter, V. L., \& Feroz, E. H. (2001). Institutional theory and accounting rule choice: an analysis of four US state governments' decisions to adopt generally accepted accounting principles. Accounting, Organizations and Society, 26(7-8), 565-596. 
Clarke, M., Seng, D., \& Whiting, R. H. (2011). Intellectual capital and firm performance in Australia. Journal of Intellectual Capital, 12(4), 505-530.

Eisenhardt, K. M. (1989). Agency theory: An assessment and review. Academy of Management Review, 14(1), $57-74$.

Frias Aceituno, J. V., Rodriguez-Ariza, L., \& GarciaSanchez, I. M. (2013). The role of the board in the dissemination of integrated corporate social reporting. Corporate Social Responsibility and Environmental Management, 20(4), 219-233.

Gilani, A., \& Geraily, S. M. (2017). Investigating the factors affecting the disclosure of intellectual capital in companies listed on the Tehran stock exchange. Marketing and Management of Innovations, 1, 280-288.

Greene, W. (2008). Econometric Analysis. Upper Saddle River, NJ: Pearson.

Hamrouni, A., Miloudi, A., \& Benkraiem, R. (2015). Signaling firm performance through corporate voluntary disclosure. Journal of Applied Business Research, 31(2), 609-620.

Hardy, C., \& Clegg, S. (1999). Studying organization: Theory \& method (Eds.). Thousand Oaks, CA: Sage.

Isnalita, I., \& Romadhon, F. (2018). The Effect of Company Characteristics and Corporate Governance on the Practices of Intellectual Capital Disclosure. International Research Journal of Business Studies, 11(3), 217-230.

Kaur, A., \& K. Lodhia, S. (2014). The state of disclosures on stakeholder engagement in sustainability reporting in Australian local councils. Pacific Accounting Review, 26(1/2), 54-74.

Khan, A., Muttakin, M. B., \& Siddiqui, J. (2013). Corporate governance and corporate social responsibility disclosures: Evidence from an emerging economy. Journal of Business Ethics, 114(2), 207-223.

Khan, H., \& Ali, M. (2010). An empirical investigation and users' perceptions on intellectual capital reporting in banks: Evidence from Bangladesh. Journal of Human Resource Costing and Accounting, 14(1), 48-69

Khan, M. H. U. Z., \& Khan, M. R. (2010). Human capital disclosure practice of top Bangladeshi companies. Journal of Human Resource Costing and Accounting, 14(4), 329-349.

Lin, L., Huang, I., Du, P., \& Lin, T. (2012), Human capital disclosure and organizational performance. Management Decision, 50(10), 1790-1799.

Madhani, P. M. (2015). A Study on the Corporate Governance and Disclosure Practices of Tangible Assets and Intangible Assets-Dominated Firms and Their Relationship. The IUP Journal of Corporate Governance, 14(2), 7-29.

Mukherjee, T., \& Sen, S. S. (2019). Intellectual Capital and
Corporate Sustainable Growth: The Indian Evidence. The East Asian Journal of Business Management, 9(2), 5-15.

Muttakin, M. B., Khan, A., \& Belal, A. R. (2015). Intellectual capital disclosures and corporate governance: An empirical examination. Advances in Accounting, 31(2), 219-227.

Ntim, C. G., Soobaroyen, T., \& Broad, M. J. (2017). Governance structures, voluntary disclosures and public accountability: The case of UK higher education institutions. Accounting, Auditing \& Accountability Journal, 30(1), 65-118.

Orens, R., Aerts, W., \& Lybaert, N. (2009). Intellectual capital disclosure, cost of finance and firm value. Management Decision, 47(10), 1536-1554.

Rahman, M. M., Sobhan, R., \& Islam, M. S. (2019). Intellectual Capital Disclosure and Its Determinants: Empirical Evidence from Listed Pharmaceutical and Chemical Industry of Bangladesh. The East Asian Journal of Business Management, 9(2), 35-46.

Rashid, A. (2013). Corporate Intellectual Capital Reporting in Bangladesh. International Journal of Learning and Intellectual Capital, 10(2), 107-121.

Taliyang, S. M., Abdul Latif, R., \& Mustafa, N. H. (2011). The determinants of intellectual capital disclosure among Malaysian listed companies. International Journal of Management and Marketing Research, 4(3), 25-33.

Taliyang, S. M., Harun, R. J., Mustafa, N. H., \& Mansor, M. (2014). Intellectual capital disclosure and market capitalization. International Journal of Business and Social Science, 5(10), 96-102.

Tejedo-Romero, F., \& Esteves, J. F. F. (2018). Management strategy and intellectual capital disclosure: influence of corporate governance. Contaduría y Administración, 63(2), 347-365.

Vitolla, F., Raimo, N., \& Rubino, M. (2019). Intellectual Capital Disclosure and Firm Performance: An Empirical Analysis through Integrated Reporting. Paper presented at the 7th International OFEL Conference on Governance, Management and Entrepreneurship: Embracing Diversity in Organisations. April 5th-6th, 2019, Dubrovnik, Croatia (245-255). Zagreb, Croatia: Governance Research and Development Centre (CIRU).

White, G., Lee, A., \& Tower, G. (2007). Drivers of voluntary intellectual capital disclosure in listed biotechnology companies. Journal of Intellectual Capital, 8(3), 517-537.

Whiting, R. H., \& Woodcock, J. (2011). Firm characteristics and intellectual capital disclosure by Australian companies. Journal of Human Resource Costing \& Accounting, 15(2), 102-126.

Zappettini, F., \& Unerman, J. (2016). 'Mixing'and 
'Bending': The recontextualisation of discourses of sustainability in integrated reporting. Discourse \& Communication, 10(5), 521-542.
Zhang, P., \& Li, N. (2005). The importance of affective quality. Communications of the ACM, 48(9), 105-108. 